\title{
Protein futures for Western Europe: potential land use and climate impacts in
} 2050

\author{
Elin Röös ${ }^{1 *}$, Bojana Bajželj ${ }^{2}$, Pete Smith ${ }^{3}$, Mikaela Patel $^{4}$, David Little ${ }^{5}$, Tara Garnett ${ }^{6}$ \\ 1 Food Climate Research Network, Environmental Change Institute, Oxford University, South Parks Road, \\ Oxford OX1 3PS, UK, elin.roos@slu.se, +46 703057710
}

2 Department of Engineering, University of Cambridge, bojana.bajzelj@wrap.org.uk

3 Institute of Biological and Environmental Sciences and ClimateXChange, University of Aberdeen, pete.smith@abdn.ac.uk

4 Department of Animal Nutrition and Management, Swedish University of Agricultural Sciences, mikaela.patel@slu.se

5 Institute of Aquaculture, University of Stirling, d.c.little@stir.ac.uk

6 Food Climate Research Network, Environmental Change Institute, Oxford University, taragarnett@ fcrn.org.uk

* Corresponding author

\begin{abstract}
Multiple production and demand side measures are needed to improve food system sustainability. This study quantified the theoretical minimum agricultural land requirements to supply Western Europe with food in 2050 from its own land base, together with GHG emissions arising. Assuming that crop yield gaps in agriculture are closed, livestock production efficiencies increased and waste at all stages reduced, a range of food consumption scenarios were modelled each based on different 'protein futures.' The scenarios were as follows: intensive and efficient livestock production using today's species mix; intensive efficient poultry-dairy production; intensive efficient aquaculture-dairy; artificial meat and dairy; livestock on 'ecological leftovers' (livestock reared only on land unsuited to cropping, agricultural residues and food waste, with consumption capped at that level of availability); and a 'plant based eating' scenario. For each scenario 'projected diet' and 'healthy diet' variants were modelled. Finally, we quantified the theoretical maximum carbon sequestration potential from afforestation of spared agricultural land. Results indicate that land use could be cut by 14 to $86 \%$ and GHG emissions reduced by up to approximately $90 \%$. The yearly carbon storage potential arising from spared agricultural land ranged from 90-700 $\mathrm{Mt} \mathrm{CO}_{2}$ in 2050. The artificial meat and plant based scenarios achieved the greatest land use and GHG reductions and the greatest carbon sequestration potential. The 'ecological leftover' scenario required the least cropland as compared with the other meat-containing scenarios, but all available pasture was used and GHG emissions were higher if meat consumption wasn't capped at healthy levels.
\end{abstract}

Keywords: Land use, climate, food, dietary change, mitigation, protein

Word count excluding references: $6,446+$ two figures $(2 \times 300$ words $)=7,046$ words 


\section{Introduction}

The current food system is unsustainable, pushing many environmental indicators beyond safe planetary boundaries (Steffen et al. 2015). To date, growing food demand has been partially met by expanding the agricultural land area (Smith et al., 2010), but the conversion of natural land has many adverse environmental consequences (Smith, 2013), including biodiversity and carbon stock losses. With the global population set to reach 9-10 billion by 2050 (UN 2012) achieving food security while staying within environmental limits poses major challenges, particularly since demand for livestock products in developing countries is growing rapidly (Godfray et al. 2010). In addition to their environmental impacts (Steinfeld et al. 2006), high meat intakes are associated with the growing prevalence of non-communicable diseases (Pan et al. 2012; Sinha et al. 2009).

The European context is the focus of this study. While the Western European population is expected to increase very little - from 440 million in 2009, to 460 million in 2050 (UN 2012) and demand for animal products unlikely to increase significantly (Alexandratos and Bruinsma 2012), European diets are on average high in animal products. Annual per capita meat and milk supply is approximately $80 \mathrm{~kg}$ and $250 \mathrm{~kg}$ respectively compared to the global average of 42 and $90 \mathrm{~kg}$ (FAO 2015b). A number of strategies have been proposed to increase food system sustainability, which variously considers either production- and/or consumptionside changes.

As regards production, key approaches proposed in the literature include: higher crop yields and increased livestock efficiencies to obtain more food per area of land or per input or per environmental damage; and technical greenhouse gas (GHG) mitigation options including improvements in land, nutrient and water management (Burney et al. 2010; Foley et al. 2011; Mueller et al. 2012; Valin et al. 2013).

Consumption side approaches include reductions of food losses (to avoid unnecessary food production) (Smith et al. 2013) and dietary changes, particularly towards reductions in meat intakes (Bajželj et al. 2014; Bryngelsson et al. 2016; Smith et al. 2013; Tilman and Clark 2014). Numerous studies have modelled alternative dietary scenarios where the meat content is varied and compensatory foods factored in, to investigate the environmental consequences, and to explore the relationship between environmental and nutritional health objectives (Röös et al. 2015; Saxe et al. 2013; Westhoek et al. 2014). A review by Hallström et al. (2015) finds that compared with the dietary status quo, emissions are $25-55 \%$ lower in vegan diets, 20 $35 \%$ in vegetarian diets and $0-35 \%$ lower in diets that are less meat intensive to varying degrees.

Previous studies indicate that both production and consumption side strategies are needed to deliver a sustainable food future (Foley et al. 2011; Tilman and Clark 2014). For example Bajželj et al. (2014) calculate that productivity increases to close yield gaps will not halt agricultural expansion, nor stabilize or decrease food-related GHG emissions (Bajželj et al. 2014). Instead, a combined approach of yield increases, food waste reduction and reductions 
in animal production and consumption to meet 'healthy diet' recommendations could halve current agricultural emissions compared with a scenario in which only yields gaps were closed and waste reduced, and would lower emissions by two thirds compared with business as usual (BAU) trajectories. Bajželj et al. (2014) only assumed minor increases in livestock production efficiencies however; potentially more can be achieved. Other studies have modelled various levels of such livestock efficiency increases (Bennetzen et al. 2016; Havlík et al. 2014; Hedenus et al. 2014; Wirsenius et al. 2010) but only considered general reductions in meat and dairy intakes. More specific dietary shifts have been proposed. One option is to replace ruminant meat with meat from monogastric animals to decrease methane emissions and increase feed conversion ratios (Hoolohan et al. 2013). Substituting meat with farmed aquatic products is another. Artificial, or in-vitro meat, and the development of novel proteins such as insects, algae and duckweed (Post 2012; van der Spiegel et al. 2013) are attracting strong interest and represent a third possibility. Finally, plant proteins such as pulses and cereals can substitute for meat and dairy in the diet. Which of these strategies that are considered relevant, desirable or plausible depend on ones values and assumptions about the nature of the food system problem (Garnett 2015). This said, in order to arrive at a more informed understanding of future options, it is necessary to investigate what the environmental implications of these possible futures might be.

Hence, the purpose of this study was calculate the land use and GHG emissions arising from a set of scenarios for Western Europe in 2050 which include both production side mitigation options and different ways in which the current dietary mix of animal products could be varied or substituted with other protein foods of non-animal origin. The work by Bajželj et al. (2014) is extended such that not only are yield gaps assumed to be closed, waste reduced and diets changed, but livestock efficiencies are also increased to correspond to current levels of highly intensive production in North-western Europe. Hence, this study quantifies the theoretical minimum agricultural land needed and GHG emissions generated from supplying the projected population of Western Europe with food produced exclusively in this region in 2050 under a range of different dietary changes, here called 'protein futures'. 


\subsection{Overview of calculation of land use and GHG emissions}

A model was built in a spreadsheet to calculate the quantity of agricultural land needed and GHGs generated to supply the projected 2050 Western European population with food for each of the scenarios (section 2.3). We define Western Europe as stretching from and including the Nordic countries in the north to Spain in the south, and from UK in the west up to but excluding Poland in the east. This area corresponds to the regions Western Europe, Northern Europe and Southern Europe as classified by the United Nations (UN 2015a). We recognize that this region currently both imports and exports foods, including animal products and animal feeds, and that future sustainable and resilient global food systems are very likely to benefit from trade. However in this study we assume that all food and feed is produced and consumed within the region. As such, we estimate the potential for supplying the Western European population with food from its own land base. This simplifies the undertaking and avoids introducing further uncertainty as regards assumptions about trade in 2050. This 'closed' approach is also relevant in relation to the EU's concept of 'community preference' through which member states are encouraged to give preference to consumption of food produced within the region (EC 2015).

In all scenarios (except the baseline BAU scenario) it is assumed that waste is reduced by $50 \%$ and, in the case of crop production, the yield gap is closed. The 50\% cut in food waste is in line with the Sustainable Development Goal 12.3 for 2030 (UN 2015b). Such reduction could potentially be achieved by regulatory and fiscal incentives and raising awareness.

Yield gaps are assumed to be relatively small for this region. They range from no gap for sugar crops, to $40 \%$ for some grains and pulses (Bajželj et al. 2014). Approaches to closing the yield gaps likely include faster knowledge and technology transfers, dissemination of and incentives for uptake of best practices, support and investment and improved forecasting. For each scenario where land is released through more efficient production and/or dietary change the carbon sequestration potential was calculated (section 2.5).

The starting point in the modelling was the amount of different food products in the diet (section 2.4). The agricultural land area needed to produce the commodities needed for the diet was then calculated as follows (and detailed in Online Resource S3). First, the caloric values of the 18 food groups included in the daily per capita diet (fruits, vegetables, wheat, rice, beef, pork, poultry, dairy, aquatic products etc.; Table S2 and S3) were translated into daily quantities (in kg) food consumed using FAO data (FAO 2011). Second, these quantities were increased to take account of losses and waste along the whole supply chain using current estimated waste and loss factors for Europe (FAO 2011) but here reduced by 50\% to account for assumed action to reduce waste. Third, the quantity of agricultural commodities needed to produce these food products was calculated based on the fraction of plant crops is actually consumed by humans (FAO 2011) e.g. for $1 \mathrm{~kg}$ of vegetable oil to be supplied, $2.9 \mathrm{~kg}$ of rapeseed is needed. For livestock products, land use for feed production was calculated by first translating the amount of an animal product (e.g. kg of milk, meat etc.) into the number 
of animals needed to produce this amount. Forage, feed grain and protein feed requirements for each animal species were then calculated based on Swedish feeding recommendations (Online Resource S4); taken to represent high feed conversion efficiency systems. Byproducts from the production of plant-based food for human consumption, mainly cereal bran and oil cake, were used as feed and livestock diets adjusted accordingly. All food and feed crops were assumed to be produced in Western Europe including protein feed although the latter is currently imported into the region to a large extent (de Ruiter et al. 2016). Finally, the land area needed to produce plant foods for human consumption and livestock feeds were calculated for each crop type, assuming closure of yield gaps, from Bajželj et al. (2014).

Greenhouse gas emissions using Global Warming Potential (GWP) over 100 years were calculated; characterization factors 25 for methane and 298 for nitrous oxide were used (Forster et al. 2007). Emissions from fertilizers, from manure and from rice cultivation were calculated following Bajželj et al. (2014); emissions in 2009 for each emission category were scaled up linearly (i.e. emission factors were kept constant). That is, the nitrous oxide emissions from fertilizer use were scaled based on the amount of fertilizer used, manure emissions based on animal products produced and methane emissions from rice based on land area used for rice cultivation (FAO 2015b). Enteric emissions needed to be calculated differently to account for increased livestock efficiencies, since these increases were not factored into Bajželj et al. (2014). Emission factors per animal (high/low-yielding dairy 109/98 kg; suckler cow $62 \mathrm{~kg}$; young cattle $44 \mathrm{~kg}$, pig $1.2 \mathrm{~kg} \mathrm{CH} 4$ per animal per year; Online Resource S5) were multiplied by the number of animals needed in each scenario. We assumed a technical potential for GHG reduction of $20 \%$ for all these emission sources (based on Smith et al. (2008)). Emissions from energy use, including the production of mineral fertilizers, are excluded as these are accounted for in the energy end-use sector (Smith et al. 2007).

\subsection{Strategies for future protein production}

How one envisions the role of livestock in future sustainable food systems depends on several value-based factors e.g. assumptions about demand and the malleability of human preferences; the role, potential and acceptability of technological innovations; the extent to which radical transformations in the workings of the global economy can be achieved; and on different underlying visions of what constitutes a sustainable and desirable food future.

Garnett (2015) describes four different 'livestock futures' based on these factors. In the first future called 'Calibrated carnivory', demand for animal products is envisaged to continue growing in the absence of political will. This demand is met through a universal shift to highly intensive livestock systems producing meat with low GHG emissions per unit of product. 'Architected flesh' similarly accepts the inevitability of growing demand, but assumes rapid and dramatic technological developments in the in-vitro meat and novel proteins sectors which are capable of meeting this demand. 'Livestock on leftovers' represents a radical departure from BAU demand assumptions as well as from current production-side approaches to addressing environmental impacts. Demand in this future is viewed as malleable and there is a shift in production emphasis away from maximizing unit efficiencies. 
Instead, livestock are produced on 'ecological leftovers' (Garnett 2009) - on land unsuited to crop production and on food waste and agricultural residues. Finally 'Fruits of the earth' envisages global public and policy acceptance of the need to radically alter diets. Meat and dairy consumption declines dramatically and diets are almost exclusively plant based.

\subsection{Scenarios modelled in this study}

This paper builds upon Garnett's (2015) livestock future in developing six different hypothetical 'protein futures' scenarios for Western Europe in 2050.

In the first of these protein futures, called the Intensive Livestock scenario and corresponding to Garnett's (2015) 'Calibrated carnivory' future, demand trajectories for all types of animal products continue in line with FAO projections (Alexandratos and Bruinsma 2012). Reduced GHG impacts per kg of meat, egg and milk produced are achieved through breeding, feeding and housing developments. All animals are reared in confined systems and fed on arable feedcrops.

The Dairy and Poultry scenario is a variant on the first. BAU demand trajectories are taken as the norm but there is an increasing global preference for poultry meat given their high feed conversion efficiency, a perception that poultry meat is healthy and its versatility - a quality that lends itself well to convenience foods. Therefore, by 2050 most meat consumed is poultry based. Ruminants (intensively reared) are still used to supply dairy products and culled cows and calves enter the meat chain, meaning that a limited quantity of ruminant meat continues to be consumed. In Intensive Livestock and in Dairy and Poultry, animal production efficiencies are assumed to increase to a level corresponding to the highly intensive systems of Northwestern Europe, modelled here as current best practice systems in Sweden (see Online Resource S4).

The Dairy and Aquaculture scenario is another variant on Intensive Livestock scenario. It too assumes that demand for animal protein continues apace but increasing health consciousness, combined with the high feed conversion efficiencies achieved by intensive aquaculture systems mean that by 2050 almost all animal flesh consumed comes from aquatic products. As in Dairy and Poultry, intensive dairying still continues. It is assumed that $80 \%$ of aquaculture products are low trophic-level finfish produced in high yielding closed recirculating systems (calculations are based on Nile tilapia) (Little et al. 2008). 20\% is supplied by mussels, oysters and other filter feeding, extractive bivalve species which do not require feed inputs.

A fourth scenario, Artificial Meat and Dairy corresponds to Garnett's (2015) 'Architected flesh.' The assumption here is that technological breakthroughs in production have been matched by consumer acceptance of in vitro meat. Both meat and dairy now can be produced by this means. Other novel proteins produced from algae and insects (reared on food waste and agricultural by-products) add to the mix. Protein production in this scenario is essentially landless. 
The Plant Based Eating scenario, corresponding with Garnett's (2015) 'Fruits of the earth', is animal free (except a small amount of seafood from wild stocks). Concerted policy actions to discourage animal product consumption, combined with growing public concerns for the environment, and with technological developments in the production of plant based novel proteins, have created a situation where diets are now universally mostly vegan. Grazing land is released for other purposes and cropland is used to produce foods for direct human consumption.

The final, sixth scenario is based on the 'Livestock on Leftovers' future in Garnett (2009) and is here called Ecological Leftovers. Here, a radical shift in policy focus and public attitudes to meat is assumed. The sustainability focus now is on achieving resource 'effectiveness' rather than efficiency (Garnett et al. 2015); an approach that aligns with current agro-ecological thinking (Francis et al. 2003). Rather than seeking to maximize livestock unit efficiencies by feeding animals crops grown on arable land, the role of farm animals in utilizing pasture land unsuited to crop production and in consuming agri-food by-products inedible to humans is emphasized. Hence in this scenario, livestock production is limited to levels achievable from using available biomass from pastures, food waste and crop and food by-products (Online Resource S6).

These six protein futures scenarios are compared against two counter scenarios. First is a BAU baseline scenario in which consumption trends follow FAO projections (Alexandratos and Bruinsma 2012); calorie intakes increase as does livestock's share of overall consumption. Yield improvements continue in line with current trends and waste is generated at current levels. Second is an 'improved baseline' scenario, here called Yields and Waste, in which the crop yield gaps are closed and waste reduced by $50 \%$, but livestock production efficiencies are as in BAU unlike in the six protein futures discussed above. Data for the BAU and Yields and Waste scenarios were taken from Bajželj et al. (2014). All scenarios are summarized in Table $\mathrm{S} 1$.

\subsection{Projected and healthy diets}

The caloric intake from animal products in the Intensive Livestock scenario, which includes all types of livestock products, was used as a baseline and all other scenarios were set to supply equivalent calories from animal products (poultry and dairy in Dairy and Poultry, aquatic products and dairy in Dairy and Aquaculture, Artificial meat and dairy in Artificial Meat and Dairy); from plant-based protein (pulses and cereals in Plant Based Eating); or from a combination of animal and plant protein (Ecological Leftovers limits livestock production to what can be produced from pastures, by-products and food waste and therefore pulses and cereals are added to the diet to reach the same caloric values and approximately the same content and mix of essential amino acids). In all scenarios 11 grams per person per day of wild seafood was included based on the current yearly catch in European waters of five million tonnes (NEF 2012). The complete diets are presented in Tables S2 and S3.

Each scenario, apart from BAU, is modelled with two dietary variants; a 'Projected Diet' and a 'Healthy diet'. In the Projected Diet variant, dietary patterns are assumed to follow current 
trends (Alexandratos and Bruinsma 2012). That is, vegetable oil and sugar intakes are in excess of healthy eating recommendations (Bajželj et al. 2014) as are animal protein intakes. For the Dairy and Aquaculture, Artificial Meat and Dairy and Plant Based Eating scenario protein intakes increase to align with terrestrial meat based equivalents. The Projected Diet of the Ecological Leftover scenario is however different as in this case the amount of animal products in the diet is determined by the amount of animal products that can be produced on pastures and from agri-food by-products and food waste, divided upon the total population.

The 'Healthy Diet' assumes a transition to diets lower in overall calories, vegetable oils, sugar and animal products, and higher in cereals, fruit and vegetables, in line with healthy eating recommendations (Bajželj et al. 2014). The Online Resource S2 provides further details.

\subsection{Use of land spared - carbon sequestration}

The land spared in the different scenarios could be used for several purposes. It could be used to sequester carbon through forest plantation or by producing biofuels to displace fossil fuels (Albanito et al. 2015). Alternatively it could be used to produce more food (or biomass for non-food purposes) for export, potentially sparing agricultural land or reducing deforestation pressures overseas. It could also be used to allow for preservation of extensive agricultural production systems with high biodiversity benefits (section 3.4). In this study, the first of these options only was quantified.

The carbon sequestration potential was calculated by first overlaying cropland and pasture data (Ramankutty et al. 2008) with data on Global Ecological Zones (FAO 2015a) to estimate the amount of pasture and cropland in different climate zones. Data from the IPCC guidelines (IPCC 2006) were used to calculate how much carbon that would be captured in above-and below-ground biomass by reforestation. The cumulative emissions up until 2050 from a linear reforestation of spared land between 2015 and 2050 was annualized over the same period and compared with the direct emissions from agriculture in the year 2050. It was assumed that the pasture and cropland used for agriculture were in carbon balance i.e. neither loosing nor sequestering carbon. Although some studies suggest perpetual C sequestration by grasslands (Soussana et al. 2007) repeat sampling surveys and long term experiments show no change is soil C over decadal time scales (see Smith 2014 for a full discussion); it was therefore judged premature to assume carbon sequestration in mature grasslands in this study.

\section{Results and discussion}

\subsection{Land use}

When livestock production is intensified large amounts of land are released. In the Intensive Livestock scenario (crop yield gaps closed, waste reduced and livestock efficiencies increased), land requirements are only half that of the Yield and Waste scenario (crop yield gaps closed and waste reduced but livestock efficiencies only slightly improved) (Fig. 1). Most of spared land is pasture; biodiversity impact of such abandonment is discussed in section 3.4. 
Land use for Dairy and Poultry and Dairy and Aquaculture is approximately $15 \%$ lower than in the Intensive Livestock scenario. This is because beef from suckler systems is replaced with poultry meat or aquaculture products, which have lower land use requirements. Overall land requirements in scenarios without any livestock production (Artificial Meat and Dairy and Plant Based Eating) are significantly less than for the other scenarios, including when and Dairy and Aquaculture) replace most ruminant meat.

In all scenarios that include animal products, Healthy Diets require less land than the Projected Diet variant since animal product intakes decline in line with healthy eating recommendations, and cereals, fruit and vegetables, consumed as substitutes, are less land intensive. However in the Artificial Meat and Dairy and Plant Based Eating scenarios, Healthy Diets are more land demanding than Projected Diets. This is because fruits, vegetables and cereals whose consumption increases in Healthy Diet, require more land than the sugar and vegetable oils they replace (Table S2).

Out of the scenarios which include livestock production, the Ecological Leftovers scenario uses the least cropland because ruminant production is mostly pasture-based and since overall meat supply is limited to what can be obtained by feeding food waste and biomass from pastures. This raises the question whether it is most valuable to spare cropland or pasture land. The amount of meat supplied is $45 \mathrm{~kg}$ carcass weight meat per person and year for the Projected Diet i.e. approximately half of current consumption in the region and very close to the global average of $46 \mathrm{~kg}$ (FAO 2015b). In the Healthy Diet the amount of meat is capped at 'healthy levels' (14 kg carcass weight per capita and year; section 2.4). 


\subsection{Greenhouse gas emissions caused by agriculture}

Closing yield gaps and reducing waste only (Yields and Waste - Projected Diet) achieves very minor GHG reductions compared to the BAU scenario since yields are already high in this region and the increased nitrous oxide emissions arising from increased fertiliser applications cancel the climate benefit of a higher yield (Fig. 2).

Compared with the Projected Diet scenario variant, Healthy Diets reduce GHG emissions drastically for the Yields and Waste, Intensive Livestock and Ecological Leftovers scenarios because less beef meat is consumed and produced. For Dairy and Poultry and Dairy and Aquaculture, emissions from Healthy Diet variants are 20-30\% lower than Projected Diets because of reduced overall animal protein intakes.

In contrast, emissions increase for Artificial Meat and Dairy and Plant Based Eating in the Healthy Diet variant since more land and fertiliser is used to produce fruits and vegetables, leading to additional nitrous oxide emissions. However, the increase is from very low levels compared with other scenarios.

The EU has a target to reduce its GHG emissions by $80 \%$ by 2050 compared to 1990 levels (EC 2011). If this target is applied equally to all sectors, GHG emissions from agriculture should not exceed $86 \mathrm{Mt} \mathrm{CO}_{2} \mathrm{e}$ per year in Western Europe by 2050. The scenarios that fall within this limit are Artificial Meat and Dairy and Plant Based Eating for both Projected Diets and Healthy Diets, and Dairy and Poultry and Dairy and Aquaculture for Healthy Diets (Fig. 2).

It could be argued that given the technical difficulties of mitigating nitrous oxide and methane emissions, and the fact that food is a 'special case' sector, a less ambitious target may be appropriate - although this would require targets for energy and transport to go beyond $80 \%$. Thus the European Commission's low carbon economy Roadmap aims for agricultural emission reductions of a modest $42-49 \%$ (EC 2011). A reduction target for agriculture of $45 \%$ for this Western Europe region would give a limit of $238 \mathrm{Mt} \mathrm{CO}_{2} \mathrm{e}$ per year. All the Healthy Diets and all Projected Diets except for the Yields and Waste and Ecological Leftovers scenarios stay within this limit. However, the Projected Diet for the Intensive Livestock scenarios is very close to the boundary and since uncertainties for these calculations are in the range of $\pm 50 \%$ or more (Röös and Nylinder 2013), it cannot be considered a 'safe' option. Hence, decreased beef meat consumption seems to be essential in order to reach the EU GHG reduction target of $45 \%$ for agriculture by 2050 even in a situation where yield gaps are closed, waste reduced and livestock efficiencies increased.

This study did not include emissions from energy use in agriculture or for post-farm activities such as processing, packaging, storage and transports. These emissions currently contribute to about half of food consumption GHGs in high income countries (Garnett 2011). Emission trajectories from the energy and transport sectors to 2050 are highly uncertain. If the reduction targets in the EU Roadmap are achieved for the transport and power sectors, this would mean GHG reductions of between 54-67\% and 93-99\% for these sectors respectively (EC 2011). In 
that case, energy and transport within the food system would add little to the total climate impact of the food system. On the other hand, if these targets are not met emissions associated with post-harvest stages in the food chain will continue to have major impacts.

\subsection{Carbon sequestration on spared land}

As regards forest plantations on spare land, Fig. 2 shows the potential annual average carbon sequestration achievable if all land were to be afforested. It is neither realistic nor desirable that all spared land is afforested; both for environmental and socioeconomic reasons (section 3.4). However, the maximum potential is shown here to avoid introducing assumptions about plausible afforestation potentials and to be consistent with the purpose of the study i.e. to show maximum potentials. Since the potential scales linearly with area, the potential can be scaled by the area considered likely to be put aside for afforestation; so for example if only $10 \%$ of the area were converted to forest, the mitigation potential would be $10 \%$ of the maximum value presented. The values for carbon dioxide captured represents the mean of all carbon sequestration between now and 2050 and it would be larger at a time closer to now and gradually lower beyond 2050 since uptake slows as trees mature. Naturally, scenarios that free more land have greater sequestration potential.

Although the carbon sequestration potential from forest plantation is large it is critical to note that carbon sequestration in biomass is reversible i.e. if forests are later cut down or destroyed by fire, sequestered carbon will return to the atmosphere. Thus the climate benefits obtain only as long as the forest is left standing. In this case however, the one-off sequestration of carbon could compensate for some level of continuous emissions of methane and nitrous oxide which are not as long-lived as carbon dioxide. To establish how much would require more detailed climate modelling than the GWP we used here. While forest planting on lowquality agricultural land could be an important short term mitigation strategy its merits need to be weighed against other land use options (Albanito et al. 2015), which are not considered here.

\subsection{Other related health and sustainability implications}

This study considered only land use and GHG emissions. Food systems generate a multitude of environmental and health impacts which need to be addressed. These include, on the environmental side, factors such as water stress and local availability of irrigation water, as well as pesticide use. The need for both may increase if diets higher in fruit and vegetables, as the Healthy Diet modelled here, supplied throughout the year are achieved (Eurostat 2007; Hess et al. 2015).

Turning to biodiversity, many threatened species in the EU depend on habitats created and maintained by low-intensity farming (Kleijn et al. 2009). In the EU27, 32\% of farmland is classified as High Nature Value (HNV) (Paracchini et al. 2008) meaning it contains high species and habitat diversity (Andersen 2003). Typical HNV areas include grasslands such as alpine meadows, the eastern and southern European steppes and the Spanish and Portugese montados (Paracchini et al. 2008) whose conservation value is usually maintained by ruminant grazing. All the scenarios modelled here, except for Ecological Leftovers, move 
food/feed production off pasture land - when in fact the consequences as regards biodiversity would probably be negative. From this perspective, the Ecological Leftovers scenario for a healthy diet may present a middle way; reducing land use and GHG emissions considerably compared to the BAU scenario, yet still entailing 30 million grazing animals that could be used to preserve HNV farmland. Of course a subset of the Ecological Leftovers scenario in which ruminant grazing is confined only to critical HNV areas could be envisaged. The impacts of different scenarios on landscape aesthetics will also vary and need to be considered, bearing in mind that preferences evolve over time.

As regards animal welfare, impacts will vary according to production system, quality of management and the extent to which health and welfare traits are included in breeding goals (Nielsen et al. 2011). Current intensive systems can cause problems such as metabolic diseases and leg disorders associated with selection for high production traits. Furthermore intensive production systems can limit the animals' ability to perform key behaviours that are important to their wellbeing, so creating stress and reducing their ability to cope (Hötzel 2014). On the other hand, more free range systems (as modelled in Ecological Leftovers) potentially give rise to a different set of problems including poor nutrition or exposure to temperature extremes. Other concerns include the spread of zoonotic diseases and livestock's role in contributing to antimicrobial resistance; the outcomes here will depend on the quality of management.

As regards human nutrition, it is important to note that animal products supply not just protein but diverse essential micronutrients including B vitamins, iron, calcium, zinc and vitamin A. A more detailed scenarios analysis would need to include requirements for these nutrients too in constructing the healthy diet variants (Millward and Garnett 2010) although it is unlikely that the broad brush findings outline here will change dramatically. A fuller analysis would also need to consider the impact of different dietary scenarios on the socio-economic determinants of good health - including the affordability of diets. Impacts of different scenarios on employment in the food sector, and on food prices would therefore need to be assessed.

\subsection{Comparison with other studies and reflections}

To our knowledge, no other study has modelled land use and GHG emissions for Western European food production in 2050 under assumptions of both production and demand side mitigation options. Our results can, however, be compared to global studies and studies of other regions in relative terms. Westhoek et al. (2014) modelled the impacts from halving the 2007 consumption of meat, dairy products and eggs in the EU27 and found that GHG emissions were reduced by $25-40 \%$ and per capita use of cropland for food production by 23\%. This is in line with our findings for the transition from Projected Diets to Healthy Diets for Intensive Livestock and Ecological Leftovers in which consumption of meat and milk are reduced by $60-70 \%$ and $23 \%$ respectively (egg consumption constant); land use decreases 12 $32 \%$ and GHG emissions by $50-60 \%$ mostly because of reduced ruminant production.

Hedenus et al. (2014) modelled global GHG emissions in 2050 and 2070 from a set of scenarios in which livestock efficiencies were increased $(+20 \%$ for beef, $+50 \%$ for dairy and 
$+25 \%$ for other meat), dedicated technical measures implemented and diets changed $(75 \%$ of red meat replaced by white meat or plant based protein). Emissions were related to the emission pathways consistent with the $2{ }^{\circ} \mathrm{C}$ target. The study concludes that the technical and production side mitigation strategies alone would not suffice to reach this target and that dietary change would also be needed.

Our study extends and complements the study by Hedenus et al. (2014) by modelling scenarios which offer extremes of potential; yield gaps closed, waste reduced and livestock intensities increased to current highest levels in all areas in the region. It shows that even under these extreme assumptions some form of dietary change will be necessary to reach EU climate change targets. On the other hand, land availability is less critical; this said either reduction in waste and/or livestock efficiency or yield increases and/or dietary change will be needed for the Western European land base to support the projected population. As regards consumption, an entirely plant-based future or a future with only artificial meat and dairy are extreme scenarios. These scenarios show enormous potential for reducing land use and GHG emissions but are of course highly open to question on grounds of public acceptability, health and other sustainability implications as discussed in section 3.4.

Clearly, a composite of the scenarios modelled here and other as yet un-investigated and unforeseen scenarios, optimised to consider a range of trade-offs (section 3.4.) is likely to be the preferable way forward considering the multiple sustainability challenges that need to be addressed. Considering the uncertain future, the need for resilience in the food system and varying consumer preferences a multitude of different protein production systems will also be needed. Nevertheless, this study clearly illustrates the need for both production and demand side strategies to reach climate change targets if Western Europe is to supply its projected population with food in 2050. Which measures to prioritise and which protein future to promote as the main vision depends on societal values and beliefs as regards technological innovations, the feasibility of achieving changes both in agricultural practices and in diet patterns and ultimately on how society chooses to conceptualise and define a sustainable food system. 


\section{Conclusion}

This study investigated a range of protein futures scenarios assuming in all cases that the full range of technically possible mitigation options were undertaken: closure of crop yield gaps, $50 \%$ reductions in food waste and livestock intensification to increase land and GHG efficiency. It found that, compared with the BAU projections for 2050, land use and GHG emissions in Western Europe could in principle be halved even if current dietary patterns were not altered. However, this is still not sufficient to reach EU climate change targets.

A shift towards healthier diets, in which fruit and vegetable intakes increased and animal products and vegetable oil intakes reduced in line with healthy eating recommendations could cut land use further still and reduce emissions to about a quarter of BAU projections.

Replacing red meat with poultry or aquaculture products reduced land use by a further $15 \%$ while GHG emissions were cut by approximately $50 \%$. The healthy diet variants of diets with poultry or aquaculture products instead of red meat achieved further small reductions in GHGs and land use requirements.

Both projected diets and healthy diets without farmed meat and dairy cut land use requirements by half again compared with the mean of diets containing meat, while GHG emissions were less than a third. Strikingly, GHG emissions from these scenarios were less than a tenth of BAU emissions while land use requirements were reduced by $80 \%$. Within these scenarios there was little variation in GHGs or land use between the projected and healthy diet variants.

An 'ecological leftovers' approach, in which livestock production is limited to use of biomass resources not used as human food, required the least cropland compared to other diets with meat, but used all available pasture. GHG emissions were $35-160 \%$ higher (depending on projected or healthy diet) than in the mean of livestock-containing scenarios based on intensive feed crop production.

The carbon sequestration potential through afforestation on land spared from agricultural production ranged between $90-700 \mathrm{Mt} \mathrm{CO}_{2}$ per year in 2050 although there was no sequestration in the BAU scenario.

\section{Acknowledgments}

Our thanks to the Future Agriculture initiative at the Swedish University of Agricultural Sciences (SLU) for funding the development of the model used to perform the calculations. 


\section{References}

Albanito F, Beringer T, Corstanje R, Poulter B, Stephenson A, Zawadzka J, and Smith P (2015) Carbon implications of converting cropland to bioenergy crops or forest for climate mitigation: a global assessment. GCB Bioenergy $8(1)$ : 81-95. doi: $10.1111 / \mathrm{gcbb} .12242$

Alexandratos N, and Bruinsma J (2012). World Agriculture Towards 2030/2050. The 2012 Revision. Food and Agriculture Organization of the United Nations, Rome

Andersen E, Baldock D, Bennet H, Beaufoy G, Bignal E, Brower F, Elbersen B, Eiden G, Godeschalk F, Jones G, McCracken D,I, Nieuwenhuizen W, van Eupen M, Hennekes S,Zervas G (2003) Developing a high nature value farming area indicator. Consultancy report to the EEA, European Environment Agency, Copenhagen

Bajželj B, Richards KS, Allwood JM, Smith P, Dennis JS, Curmi E, Gilligan CA (2014) Importance of food-demand management for climate mitigation. Nature Climate Change 4(10): 924-929. doi: 10.1038/nclimate2353

Bennetzen EH, Smith P, Porter JR (2016) Decoupling of greenhouse gas emissions from global agricultural production: 1970-2050. Global Change Biology 22(2): 763-781. doi: 10.1111/gcb.13120

Bryngelsson D, Wirsenius S, Hedenus F, and Sonesson U (2016) How can the EU climate targets be met? A combined analysis of technological and demand-side changes in food and agriculture. Food Policy 59: 152-164. doi:10.1016/j.foodpol.2015.12.012

Burney JA, Davis SJ, Lobell DB (2010) Greenhouse gas mitigation by agricultural intensification. Proceedings of the National Academy of Sciences 107(26): 12052-12057. doi: 10.1073/pnas.0914216107

de Ruiter H, Macdiarmid JI, Matthews RB, Kastner T, and Smith P (2016) Global cropland and greenhouse gas impacts of UK food supply are increasingly located overseas. Journal of The Royal Society Interface 13(114). doi:10.1098/rsif.2015.1001

EC (2011) A Roadmap for moving to a competitive low carbon economy in 2050. COM(2011) 112 final. European Commission, Brussels

EC (2015) The early years: establishment of the CAP. European Commission. http://ec.europa.eu/agriculture/caphistory/early-years/index_en.htm. Accessed 4 May 2016

Eurostat (2007) The use of plant protection products in the European Union Data 1992-2003. 2007 Revision, European Commission, Brussels

FAO (2011) Global food losses and food waste - Extent causes and prevention. Food and Agriculture Organization of the United Nations, Rome

FAO (2015a) FAO Geonetwork. Find and analyze geo-spatial data. Food and Agriculture Organization of the United Nations, Rome. http://www.fao.org/geonetwork. Assessed 2 Feb 2015

FAO (2015b) FAOSTAT. Food and Agriculture Organization of the United Nations, Rome. http://faostat.fao.org/default.aspx Assessed 6 March 2015

Foley JA, Ramankutty N, Brauman KA, Cassidy ES, Gerber JS, Johnston M, Mueller ND, O'Connell C, Ray DK, West PC, Balzer C, Bennett EM, Carpenter SR, Hill J, Monfreda C, Polasky S, Rockström J, Sheehan J, Siebert S, Tilman D, Zaks DPM (2011) Solutions for a cultivated planet, Nature 478(7369): 337-342.

Forster P, Ramaswamy V, Artaxo P, Berntsen T, Betts R, Fahey DW, Haywood J, Lean J, Lowe DC, Myhre G, Nganga J, Prinn R, Raga G, Schulz M, Van Dorland R (2007) Changes in Atmospheric Constituents and in Radiative Forcing. In: Solomon S, Qin D, Manning M, Chen Z, Marquis M, Averyt KB, Tignor M, Miller HL (eds) Climate Change 2007: The Physical Science Basis, Contribution of Working Group I to the Fourth Assessment Report of the Intergovernmental Panel on Climate Change, Cambridge University Press, Cambridge and New York

Francis C, Lieblein G, Gliessman S, Breland T, A, Creamer N, Harwood R, Salomonsson L, Helenius J, Rickerl D, Salvador R, Wiedenhoeft M, Simmons S, Allen P, Altieri M, Flora C, Poincelot R (2003) Agroecology: The Ecology of Food Systems. Journal of Sustainable Agriculture 22(3): 99-118. doi: 10.1300/J064v22n03_10

Garnett T (2009) Livestock-related greenhouse gas emissions: impacts and options for policy makers, Environmental Science and Policy 12(4): 491-503. doi: 10.1016/j.envsci.2009.01.006

Garnett T (2011) Where are the best opportunities for reducing greenhouse gas emissions in the food system (including the food chain)? Food Policy 36(SUPPL, 1):S23-S32

Garnett T (2015) Gut feelings and possible tomorrows: (where) does animal farming fit? Food Climate Research Network, University of Oxford, Oxford

Garnett T, Röös E, Little D (2015) Lean green mean obscene...? What is efficiency? And is it sustainable? Food Climate Research Network, University of Oxford, Oxford

Godfray C, Beddington JR, Crute IR, Haddad L, Lawrence D, Muir JF, Pretty J, Robinson S, Thomas SM, Toulmin C (2010) Food Security: The Challenge of Feeding 9 Billion People, Science 327(5967): 812-818. doi: $10.1126 /$ science. 1185383

Hallström E, Carlsson-Kanyama A, Börjesson P (2015) Environmental impact of dietary change: a systematic review, Journal of Cleaner Production 91(0): 1-11. doi:10.1016/j.jclepro.2014.12.008

Havlík P, Valin H, Herrero M, Obersteiner M, Schmid E, Rufino MC, Mosnier A, Thornton PK, Böttcher H, Conant RT, Frank S, Fritz S, Fuss S, Kraxner F, Notenbaert A (2014) Climate change mitigation through livestock system transitions. Proceedings of the National Academy of Sciences 111(10): 3709-3714. doi: 10.1073/pnas.1308044111

Hedenus F, Wirsenius S, Johansson DA (2014) The importance of reduced meat and dairy consumption for meeting stringent climate change targets. Climatic Change 124(1-2): 79-91. doi: 10.1007/s10584-014-1104-5

Hess T, Andersson U, Mena C, Williams A (2015) The impact of healthier dietary scenarios on the global blue water scarcity footprint of food consumption in the UK. Food Policy 50(0): 1-10. doi:10.1016/j.foodpol.2014.10.013 
Hoolohan C, Berners-Lee M, McKinstry-West J, Hewitt CN (2013) Mitigating the greenhouse gas emissions embodied in food through realistic consumer choices. Energy Policy 63(0): 1065-1074. doi: 10.1016/j.enpol.2013.09.046

Hötzel MJ (2014) Improving Farm Animal Welfare: Is Evolution or Revolution Needed in Production Systems? In: Appleby MC, Weary DM, Sandoe P (eds) Dilemmas in Animal Welfare, CABI, Wallingford

IPCC (2006) 2006 IPCC Guidelines for National Greenhouse Gas Inventories. Intergovernmental Panel on Climate Change, Geneva

Kleijn D, Kohler F, Báldi A, Batáry P, Concepción E, D, Clough Y, Díaz M, Gabriel D, Holzschuh A, Knop E, Kovács A, Marshall EJP, Tscharntke T, Verhulst J (2009) On the relationship between farmland biodiversity and land-use intensity in Europe, Proc. R. Soc. B 276: 903-909

Little DC, Murray FJ, Azim E, Leschen W, Boyd K, Watterson A, Young JA (2008) Options for producing a warm-water fish in the UK: limits to "Green Growth"? Trends in Food Science and Technology 19(5): 255-264. doi: http://dx.doi.org/10.1016/j.tifs.2007.12.003

Millward JD Garnett T (2010) Plenary Lecture 3 Food and the planet: nutritional dilemmas of greenhouse gas emission reductions through reduced intakes of meat and dairy foods, Proceedings of the Nutrition Society 69(01): 103-118, doi: doi:10.1017/S0029665109991868

Mueller ND, Gerber JS, Johnston M, Ray DK, Ramankutty N, Foley JA (2012) Closing yield gaps through nutrient and water management. Nature 490(7419): 254-257. doi: http://www.nature.com/nature/journal/v490/n7419/abs/nature11420.html\#supplementary-information

NEF (2012) Fish Dependence - 2012 Update. The increasing reliance of the EU on fish from elsewhere, New Economics Foundation, London

Nielsen HM, Olesen I, Navrud S, Kolstad K, Amer P (2011) How to Consider the Value of Farm Animals in Breeding Goals, A Review of Current Status and Future Challenges. Journal of Agricultural and Environmental Ethics 24(4): 309 330. doi: 10,1007/s10806-010-9264-4

Pan A, Sun Q, Bernstein AM, Schulze MB, Manson JW, Stampfer MJ, Willett WC, Hu FB (2012) Red meat consumption and mortality: Results from 2 prospective cohort studies. Archives of Internal Medicine 172(7): 555-563. doi: 10.1001/archinternmed.2011.2287

Paracchini ML, Petersen JE, Hoogeveen Y, Bamps C, Burfield I, van Swaay C (2008) High Nature Value Farmland in Europe. An estimate of the distribution patterns on the basis of land cover and biodiversity data. EUR $23480 \mathrm{EN}-$ 2008. Joint Research Centre, European Commisson, Ispra

Post MJ (2012) Cultured meat from stem cells: Challenges and prospects. Meat Science 92(3): 297-301. doi: 10.1016/j.meatsci.2012.04.008

Ramankutty N, Evan AT, Monfreda C, Foley JA (2008) Farming the planet: 1. Geographic distribution of global agricultural lands in the year 2000. Global Biogeochemical Cycles 22(1):GB1003. doi: 10.1029/2007GB002952

Röös E, Karlsson H, Witthöft C, Sundberg C (2015) Evaluating the sustainability of diets-combining environmental and nutritional aspects, Environmental Science and Policy 47(0):157-166. doi: 10.1016/j.envsci.2014.12.001

Röös E, Nylinder J (2013) Uncertainties and Variations in the Carbon Footprint of Livestock Products. Report 063. Department of Energy and Technology, Swedish University of Agricultural Sciences, Uppsala

Saxe H, Larsen TM, Mogensen L (2013) The global warming potential of two healthy Nordic diets compared with the average Danish diet. Climatic Change 116(2): 249-262

Sinha R, Cross AJ, Graubard BI, Leitzmann MF, Schatzkin A (2009) Meat intake and mortality: A prospective study of over half a million people, Archives of Internal Medicine 169(6): 562-571. doi: 10.1001/archinternmed.2009.6

Smith P (2013) Delivering food security without increasing pressure on land. Global Food Security 2(1): 18-23. doi: 10.1016/j.gfs.2012.11.008

Smith P (2014) Do grasslands act as a perpetual sink for carbon? Global Change Biology 20(9): 2708-2711. doi: $10.1111 / \mathrm{gcb} .12561$

Smith P, Gregory PJ, Van Vuuren D, Obersteiner M, Havlík P, Rounsevell M, Woods J, Stehfest E, Bellarby J (2010) Competition for land. Philosophical Transactions of the Royal Society B: Biological Sciences 365(1554): 29412957.

Smith P, Haberl H, Popp A, Erb K,-h, Lauk C, Harper R, Tubiello FN, de Siqueira Pinto A, Jafari M, Sohi S, Masera O, Böttcher H, Berndes G, Bustamante M, Ahammad H, Clark H, Dong H, Elsiddig EA, Mbow C, Ravindranath, NH, Rice CW, Robledo Abad C, Romanovskaya A, Sperling F, Herrero M, House JI, Rose S (2013) How much landbased greenhouse gas mitigation can be achieved without compromising food security and environmental goals? Global Change Biology 19(8): 2285-2302. doi: 10.1111/gcb.12160

Smith P, Martino D, Cai Z, Gwary D, Janzen H, Kumar P, McCarl B, Ogle S, O'Mara F, Rice C, Scholes B, Sirotenko O, Howden M, McAllister T, Pan G, Romanenkov V, Schneider U, Towprayoon S, Wattenbach M, Smith J (2008) Greenhouse gas mitigation in agriculture. Philosophical Transactions of the Royal Society B: Biological Sciences 363(1492): 789-813

Smith P, Martino D, Cai Z, Gwary D, Janzen H, Kumar P, McCarl B, Ogle S, O’Mara F, Rice C, Scholes B, Sirotenko O (2007) Agriculture. In: Metz B, Davidson OR, Bosch PR, Dave R, Meyer LA (eds) Climate Change 2007: Mitigation, Contribution of Working Group III to the Fourth Assessment Report of the Intergovernmental Panel on Climate Change. Cambridge University Press, Cambridge and New York

Soussana JF, Allard V, Pilegaard K, Ambus P, Amman C, Campbell C, Ceschia E, Clifton-Brown J, Czobel S, Domingues R, Flechard C, Fuhrer J, Hensen A, Horvath L, Jones M, Kasper G, Martin C, Nagy Z, Neftel A, Raschi A, Baronti S, Rees RM, Skiba U, Stefani P, Manca G, Sutton M, Tuba Z, Valentini R (2007) Full accounting of the greenhouse 
gas $\left(\mathrm{CO}_{2} \mathrm{~N}_{2} \mathrm{O} \mathrm{CH} 4\right)$ budget of nine European grassland sites. Agriculture Ecosystems and Environment 121(1-2): 121-134. doi: 10.1016/j.agee.2006.12.022

Steffen W, Richardson K, Rockström J, Cornell SE, Fetzer I, Bennett EM, Biggs R, Carpenter SR, de Vries W, de Wit CA, Folke C, Gerten D, Heinke J, Mace GM, Persson LM, Ramanathan V, Reyers B, Sörlin S (2015) Planetary boundaries: Guiding human development on a changing planet. Science 347(6223). doi:10.1126/science.1259855

Steinfeld H, Gerber P, Wassenaar T, Castel V, Rosales M, de Haan C (2006) Livestock's Long Shadow: Environmental Issues and Options. Food and Agriculture Organization of the United Nations, Rome

Tilman D, Clark M (2014) Global diets link environmental sustainability and human health. Nature 515(7528): 518-522. doi: 10.1038/nature13959

UN (2012) World Population Prospects: The 2012 Revision. United Nations, New York

UN (2015a) Composition of macro geographical (continental) regions geographical sub-regions and selected economic and other groupings. United Nations. http://unstats.un.org/unsd/methods/m49/m49regin.htm. Assessed 6 April 2015

UN (2015b) Sustainable Development Goals. United Nations. https://sustainabledevelopment.un.org/?menu=1300. Assessed 10 May 2016

Valin H, Havlík P, Mosnier A, Herrero M, Schmid E, Obersteiner M (2013) Agricultural productivity and greenhouse gas emissions: trade-offs or synergies between mitigation and food security? Environmental Research Letters 8(3): 035019. doi: 10.1088/1748-9326/8/3/035019

van der Spiegel M, Noordam MY, van der Fels-Klerx HJ (2013) Safety of Novel Protein Sources (Insects Microalgae Seaweed Duckweed and Rapeseed) and Legislative Aspects for Their Application in Food and Feed Production. Comprehensive Reviews in Food Science and Food Safety 12(6): 662-678. doi:10.1111/1541-4337.12032

Westhoek H, Lesschen JP, Rood T, Wagner S, De Marco A, Murphy-Bokern D, Leip A, van Grinsven H, Sutton MA, Oenema O (2014) Food choices health and environment: Effects of cutting Europe's meat and dairy intake. Global Environmental Change 26(0): 196-205. doi:10.1016/j.gloenvcha.2014.02.004

Wirsenius S, Azar C, Berndes G (2010) How much land is needed for global food production under scenarios of dietary changes and livestock productivity increases in 2030? Agricultural Systems 103(9): 621-638. doi: 10.1016/j.agsy.2010.07.005 